\title{
THE INFLUENCE OF STAD TYPE COOPERATIVE LEARNING MODEL ON IMPROVING PHYSICS LEARNING PROCESS AND LEARNING OUTCOMES
}

\author{
M. Yusuf As \\ Teacher at State Vocational High School 1 Narmada, West Lombok, Indonesia \\ Email: hajiyusuf64@gymail.com
}

Acceped: August 27 2021. Approved: August 31 2021. Published: Sept 042021

\begin{abstract}
Efforts on improving student's process and learning outcomes using STAD type cooperative learning model involve the following stages: (1) teaching: presenting the lesson; (2) discussion: students work in their groups guided by activity sheets to complete the subject matter; (3) test: students take the quiz individually; and (4) group reward: the data collected in this study consist of activity observation data, questionnaire, and learning outcomes test. This study revealed that the student's activities were categorized as very active in cycle 1 , very active in cycle 2 , and very active in cycle 3 . The teacher's activities were in the very active category during the three cycles. The average cognitive aspect of students was 76 , with classical completeness of $74 \%$ in cycle 1 . The average cognitive aspect of students was 75 , with classical completeness of $83 \%$ in cycle 2 . Meanwhile, the average score of cognitive aspect was 82 with classical completeness of $91 \%$ in cycle 3 . ANOVA analysis on the treatment of each cycle showed a significant influence with a value of 0.01 below 0.05 . Based on this data, applying the STAD type cooperative learning model can improve first-year students' learning process and outcomes in Physics lessons at State Vocational High School 1 Narmada.
\end{abstract}

Keywords: Cooperative learning, STAD, learning process, learning outcome

\section{INTRODUCTION}

The 2013 curriculum is a learning curriculum directed to developing the ability to know, understand, perform things, live together, and self-actualize. Learning activities need to be studentcentered, develop student creativity, create fun and challenging conditions, contain values, ethics, aesthetics, logic, and kinesthetics, and provide diverse learning experiences [1]. In the 2013 curriculum, students are declared to have achieved learning completeness if they have been able to acquire at least $75 \%$ of the entire material (especially for subjects that have a higher level of difficulties such as Mathematics and Natural Sciences) individually [2-4]. If they reach a higher than $85 \%$ score of all students, they have achieved learning classical completeness of $75 \%$ (Department of National Education, 2003). The Indonesian state does not differentiate the application of this curriculum [5]. The difference in the curriculum is the individual's ability to absorb concepts from learning materials.

Observation and study during the implementation of learning assignments at State Vocational High School 1 Narmada revealed that learning completeness for science subjects (Physics) in the first year was not optimal with the Minimum Completeness Criteria (MCC) determined by the school of 70 (still below the $75 \%$ Completeness Standard individually). The description of this situation can be seen in table 1 .

Learning completeness of first-year students at State Vocational High School 1 Narmada students in science lessons was still not optimal. Learning outcomes are influenced by several factors both within themselves and in student's learning environment. Since State Vocational High School 1 Narmada was a relatively new school in Narmada District, prospective students were not familiar with the school's existence. Facilities and learning resources that support the achievement of student learning completeness were still limited. In addition, the methods used by teachers in learning were still dominated by classical teaching and lecture methods without being interspersed with the methods that challenge students to attempt. The main phenomenon that we faced in this class was that students were less participatory, less involved, and did not have the initiative and contribution both intellectually and emotionally, thus teaching tends to be rigid and teacher-centered.

The paradigm shift in education word from teacher-centered learning to more student-centered learning seems to be more effective in optimizing the learning process and improving student learning outcomes. Cooperative learning (one of the learning models that is student-centered) positively impacts students with low learning outcomes. In cooperative learning, the more capable students help the less capable ones [6-8].

Several types of cooperative learning include Student Teams-Achievement Division (STAD), Teams-Games-Tournament (TGT), Jigsaw II, Cooperative Integrated Reading and Composition (CIRC), and Team Accelerated Instruction (TAI). The STAD type cooperative learning model is very suitable for teaching learning objectives formulated with one answer as found in mathematics and science. The model is also suitable to be applied in chemistry learning [9]. The STAD type cooperative learning model can optimize the learning process 
and improve student learning outcomes in chemistry

subjects [10].

Table 1. The average score of students

\begin{tabular}{|l|l|l|}
\hline Evaluation Type & Average Student Score & Classical Completeness Percentage \\
\hline Daily tests 1 dan 2 & 65,6 & $71,8 \%$ \\
\hline $\begin{array}{l}\text { End-semester exam in the first } \\
\text { semester }\end{array}$ & 71,2 & $78,3 \%$ \\
\hline $\begin{array}{l}\text { Student's final grade in the first } \\
\text { semester }\end{array}$ & 69,0 & $72,8 \%$ \\
\hline
\end{tabular}

The application of the student-centered STAD type cooperative learning model needs to be conducted at State Vocational High School 1 Narmada to further motivate students in a more active and effective learning process. Student's more active manner will increase their knowledge in learning, and therefore, improve the process and outcomes of science learning.

\section{RESEARCH METHOD \\ Research Type and Design}

The study is classroom action research, which aims to upgrade or improve learning practices in the direction that teachers should conduct in teaching. [11-12]. Classroom action research (CAR) design consists of 3 (three) cycles, with four (4) interrelated and continuous stages: (1) planning, (2) action, (3) observing, and (4) reflecting [13-15]. The design of CAR can be seen in Figure 1 [16].

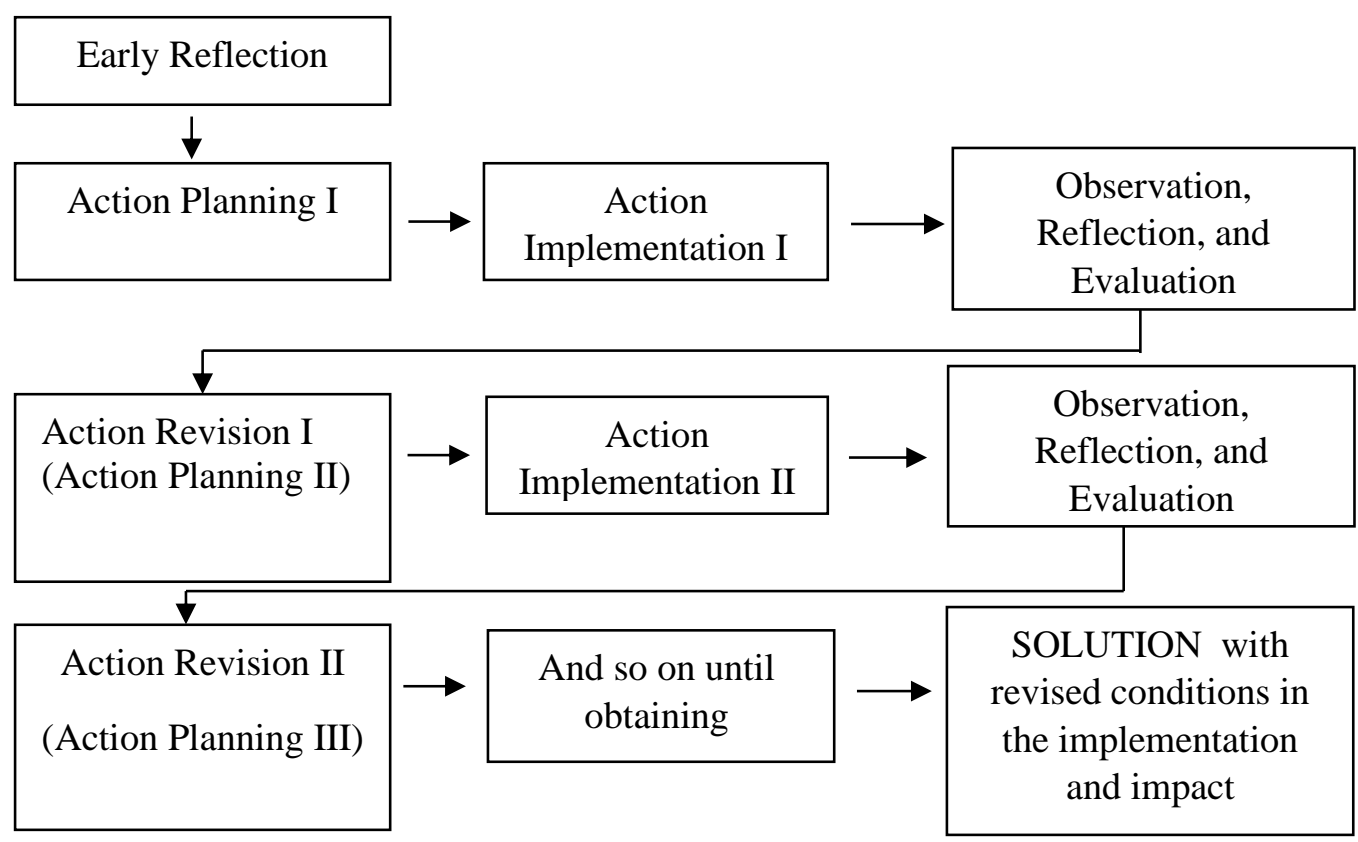

Figure 1. Classroom Action Research Design

\section{Research Instruments and Data Analysis}

The research instruments developed for data collection consist of observation sheets, questionnaires, and learning outcomes tests. An observation sheet is used to obtain an overview of the learning process using the STAD (Student Team Achievement Division) cooperative model related to teacher and student activities during the learning process. Students were given a questionnaire accommodating seven attitudes/response indicators compiled and developed by the researcher at the end of each meeting to find out the attitudes and responses (affective) of students participating in learning with the STAD type cooperative learning model. The researcher prepared the instrument for measuring students' cognitive aspect in the form of objective essay questions consisting of 6 questions in cycle 1, 6 questions in cycle 2 , and 7 questions in cycle 3 . The test was given in the form of a performance test carried out at the end of cycle 3 to determine student's psychomotor skills on the solubility and solubility product concept.

Observation data were analyzed with several steps, including analyzing and summarizing the observation results for each cycle based on the 
observation sheet. Observation on activities was also analyzed and summarized.

Indicators of teacher activity involved teacher activity in guiding students, teacher ability to create a conducive classroom atmosphere, and the way teacher provided subject matter to be discussed. In addition, the results of observations about student activities in participating in learning with the STAD type cooperative model were analyzed and summarized. Indicators of student activity include student enthusiasm in participating in teaching and learning activities, student-teacher interaction, student-student interaction, group collaboration, student activity in group discussions, student activity in learning, and student participation in concluding learning outcomes.
Learning outcomes were analyzed using quantitative descriptive. The analysis reflects student's level of understanding in the learning process, which is determined by the percentage of understanding and classical completeness.

\section{RESULT AND DISCUSSION Student activity profile}

Student activity profile in participating in learning activities with the STAD type cooperative learning model in 3 (three) cycles is described in table 2. Based on the observation data, it is clear that the STAD type cooperative learning model positively impacts student learning activities. Students become more active and participative in carrying out learning activities.

Table 2. Profile of student activities in participating in learning

\begin{tabular}{lccc}
\multicolumn{1}{c}{ Observed Aspects } & \multicolumn{2}{c}{ Average Score Per Cycle } \\
& Cycle 1 & Cycle 2 & Cycle 3 \\
\hline $\begin{array}{l}\text { I am very enthusiastic about participating in teaching and learning } \\
\text { activities }\end{array}$ & 3,5 & 3,6 & 3,6 \\
This lesson provides many opportunities for interaction between & 3,3 & 3,3 & 3,5 \\
students and the teacher & & 3,4 & 3,5 \\
This lesson also provides many opportunities for interaction among & 3,5 & 3,4 & 3,5 \\
the students & 3,3 & 3,4 & 3,4 \\
This lesson prioritizes optimal group collaboration. & 3,4 & 3,2 & 3,3 \\
Student activities in a group discussion can excite my learning & 3,0 & 3,0 & 3,4 \\
enthusiasm & 3,0 & 3,3 \\
Student activity in learning is very high, so the lesson is not tedious & 3,0 & 24,2 \\
Student participation in concluding learning outcomes is very high & 3,3 & 23,3 & 23,2 \\
Total & Very & Very & Very \\
Classification & active & active & active \\
\hline
\end{tabular}

\section{Teacher activity profile}

Teacher activity profile in carrying out learning activities with STAD type cooperative learning model in 3 (three) cycles are represented in table 3. Observation data of teacher activities in conducting learning with STAD type cooperative learning model indicated that teachers are very active in guiding students, creating a conducive learning atmosphere in the classroom, and in providing material to be discussed by students.

\section{Student learning outcome}

The learning outcomes of cognitive aspects in the research are obtained directly and instantly (table 5). Thus they describe the level of student comprehension of the topic they have just finished discussing. Tests for measuring the cognitive aspects of students in the first, second, and third cycles were arranged in the form of objective essay tests. It was because objective essay questions are most useful for testing higher levels of cognitive thinking. In particular, teaching objectives at the levels of analysis, synthesis, and evaluation can be measured if students are asked to organize and express their thoughts in a structured framework, describe relationships, and defend opinions in writing [17].

The objective essay test in the first cycle consisted of 6 questions, that in the second cycle consisted of 6 questions, while that in the third cycle consisted of 7 questions so that the total items used to measure student learning outcomes in this study were 19 items. According to the table of learning outcomes, the maximum score obtained by students in the first cycle was 100 (one hundred), and the minimum score was 33.0 , with a completeness rate of $74 \%$. It means that it must be continued to the next cycle because it has not reached $85 \%$ learning completeness. Hence, further research was applied with the second cycle, after first conducting a revision and reflection on the activities in cycle 1 to minimize the deficiencies in the first cycle. After implementing learning and test in the second cycle, the highest score of 100 and the lowest score of 44 , 
and the average score of 75 indicated an improvement compared to the results obtained in the first cycle with classical learning completeness of $83 \%$. Despite the increase in learning outcomes in this second cycle of learning, we still have not achieved the work indicator with the completeness of $85 \%$, and therefore, we need to continue to the third cycle of classroom action research [18].

After revising learning tools and actions that were still not effective in cycles 1 and 2, data collection was conducted again in the third cycle, whose learning outcomes were presented in table 3 . According to the table of learning outcomes for the third cycle, the highest score was 100 . The lowest score was 50 . The average score was 82 , with classical learning completeness of $91 \%$. Thus the classical comprehension target of $85 \%$ has been exceeded. Hence, STAD-type cooperative model can be an adequate learning model in improving student learning outcomes [19-20].

The STAD cooperative model's application improves students' understanding gradually according to the development of learning in each cycle. The increase in concept understanding is supported by the results of the ANOVA analysis, which is below 0.05 with a value of 0.011 (Table 6).

\section{Student Affective Learning Outcomes}

Students' affective aspects were assessed by giving a questionnaire containing students' responses (attitudes) to the STAD type cooperative learning process. The questionnaire was compiled and developed by the researcher and accommodated 7 points of student attitude indicators.

Student-centered learning stimulates the students to be more active and motivated in learning. The STAD learning model raises student's motivation into the very active category. In learning, we are expected to pay more attention to the condition of students before starting the lesson [21]. Student learning motivation establishes student attitudes in learning and the desire to improve understanding [22]. The achievements of each student must be rewarded as recompense and awards in the learning process.

Table 3. Profile of teacher activities in conducting learning

\begin{tabular}{lccc}
\hline \multirow{2}{*}{ Criteria } & \multicolumn{3}{c}{ Average Score } \\
& Cycle 1 & Cycle 2 & Cycle 3 \\
\hline Active in guiding students & 4 & 5 & 5 \\
Able to create a conducive atmosphere & 5 & 5 & 5 \\
Provide material to be discussed & 4 & 4 & 5 \\
Total Score & 13 & 14 & 15 \\
Classification & Very & Very & Very \\
& active & active & active \\
\hline
\end{tabular}

Table 5. Student Learning Outcomes

\begin{tabular}{cccc}
\hline Aspect & \multicolumn{3}{c}{ Score } \\
Cycle 2 & Cycle 3 \\
\hline The highest score & 100 & 100 & 100 \\
The lowest score & 33 & 44 & 50 \\
Average score & 76 & 75 & 82 \\
Classical learning completeness & 74 & 83 & 91 \\
Standard deviation & 19 & 14 & 12 \\
\hline
\end{tabular}

Table 6. ANOVA Analysis Results

\begin{tabular}{|c|c|c|c|c|c|}
\hline \multicolumn{6}{|c|}{ ANOVA } \\
\hline \multirow{3}{*}{ Between Groups } & & & & & \\
\hline & Sum of Squares & df & Mean Square & $\mathrm{F}$ & Sig. \\
\hline & 1064.880 & 1 & 1064.880 & 6.665 & .011 \\
\hline Within Groups & 14379.239 & 90 & 159.769 & & \\
\hline Total & 15444.120 & 91 & & & \\
\hline
\end{tabular}


Table 7. Summary of Affective Aspect Data

\begin{tabular}{lccc}
\hline \multicolumn{1}{c}{ Observed aspect } & \multicolumn{3}{c}{ Average Score } \\
& Cycle 1 & Cycle 2 & Cycle 3 \\
\hline $\begin{array}{l}\text { I am very enthusiastic about participating in teaching and } \\
\text { learning activities }\end{array}$ & 3,5 & 3,6 & 3,6 \\
$\begin{array}{l}\text { This lesson provides many opportunities for interaction } \\
\text { between students and the teacher }\end{array}$ & 3,3 & 3,3 & 3,5 \\
$\begin{array}{l}\text { This lesson also provides many opportunities for interaction } \\
\text { among the students }\end{array}$ & 3,5 & 3,4 & 3,5 \\
$\begin{array}{l}\text { This lesson prioritizes optimal group collaboration. } \\
\text { Student activities in a group discussion can excite my learning }\end{array}$ & 3,3 & 3,4 & 3,5 \\
enthusiasm & 3,4 & 3,2 & 3,4 \\
$\begin{array}{l}\text { Student activity in learning is very high, so the lesson is not } \\
\text { tedious }\end{array}$ & 3,0 & 3,0 & 3,3 \\
$\begin{array}{l}\text { Student participation in concluding learning outcomes is very } \\
\text { high } \quad \text { Total Score }\end{array}$ & 3,3 & 3,3 & 3,4 \\
$\quad$ Classification & 23,3 & 23,2 & 24,2 \\
& Very & Very & Very \\
& active & active \\
\hline
\end{tabular}

\section{REFERENCES}

[1] Sanjaya, W. (2006). Pembelajaran dalam implementasi kurikulum berbasis kompetensi. Kencana.

[2] Mardapi, D., \& Ghofur, A. (2004). Pedoman Umum Pengembangan Penilaian; Kurikulum Berbasis Kompetensi SMA. Jakarta: Direktorat Pendidikan Menengah Umum.

[3] Septian, A., \& Komala, E. (2019). Kemampuan Koneksi Matematik dan Motivasi Belajar Siswa dengan Mengunakan Model Problem-Based Learning (PBL) Berbantuan Geogebra di SMP. Prisma, 8(1), 1-13.

[4] Widdiharto, R. (2004). Model-Model Pembelajaran Matematika SMP. Jakarta: Depdiknas.

[5] Uyun, I. (2018). Implementasi Kurikulum 2013 dalam Meningkatkan Pemahaman Siswa Tunagrahita pada Mata Pelajaran PAI di SLB Negeri Cendono Jenjang SDLB Tahun Pelajaran 2018/2019 (Doctoral dissertation, IAIN KUDUS).

[6] Septian, A., Agustina, D., \& Maghfirah, D. (2020). Model Pembelajaran Kooperatif Tipe Student Teams Achievement Division (STAD) untuk Meningkatkan Pemahaman Konsep Matematika. Mathema: Jurnal Pendidikan Matematika, 2(2), 10-22.

[7] Hartati, N., Artayasa, P., \& Lestari, N. (2013). Pengaruh Model Pembelajaran Kooperatif Tipe Talking Stick (Tongkat Berbicara) Terhadap Hasil Belajar Biologi Siswa Kelas X SMA Negeri 2 Labuapi Tahun Ajaran 2011/2012. Jurnal Pijar Mipa, 8(1).

[8] Ariani, M. D., Baidowi, B., \& Azmi, S. (2014). Penerapan Pembelajaran Dengan Bantuan Bertahap (Scaffolding) Untuk Meningkatkan
Aktivitas Dan Prestasi Belajar Matematika Siswa Pada Materi Pokok Trigonometri Kelas XB Semester II Sman 1 Labuapi Tahun Pelajaran 2013/2014. Jurnal Pijar Mipa, 9(2).

[9] Risdiawati, Y. R. (2012). Implementasi model pembelajaran kooperatif tipe student teams achievement divisions (STAD) untuk meningkatkan motivasi dan hasil belajar akuntansi siswa kelas XI IPS 4 SMA Negeri 1 Imogiri tahun ajaran 2011/2012. Kajian Pendidikan Akuntansi Indonesia, 1(2).

[10] Hidayati, I. N. A., Redjeki, T., \& Hastuti, B. (2013). Penerapan model pembelajaran kooperatif tipe Student Team Achievement Division (STAD) untuk meningkatkan aktivitas dan prestasi belajar kimia pada materi pokok kesetimbangan kimia siswa kelas XI MAN Klaten tahun pelajaran 2011/2012. Jurnal Pendidikan Kimia, 2(2), 92-99.

[11] Susilowati, D. (2018). Penelitian Tindakan Kelas (PTK) solusi alternatif problematika pembelajaran. Jurnal Ilmiah Edunomika, 2(01).

[12] Mulia, D. S., \& Suwarno, S. (2016). PTK (Penelitian Tindakan Kelas) Dengan Pembelajaran Berbasis Kearifan Lokal Dan Penulisan Artikel Ilmiah Di Sd Negeri Kalisube, Banyumas. Khazanah Pendidikan, 9(2).

[13] Suprayekti. (2003). Intereaksi Balajar Mengajar. Jakarta: Depdiknas.

[14]Hanifah, N. (2014). Memahami penelitian tindakan kelas: teori dan aplikasinya. UPI Press.

[15] Arikunto, S. (2021). Penelitian tindakan kelas: Edisi revisi. Bumi Aksara.

[16] Indrawati. 2001. Penelitian Tindakan Kelas (Classroom Action Research). Bandung: Pusat Penataran Guru IPA. 
[17] Lahim, L. (2018). MENINKATKAN PROSES DAN HASIL BELAJAR IPA MELALUI MODEL PEMBELAJARAN KOOPERATIF TIPE STAD DI KELAS VIII SMPN 1 PUJUT. Justek: Jurnal Sains dan Teknologi, 1(1), 132139.

[18] Jana, P., \& Pamungkas, B. (2018). Pelatihan penelitian tindakan kelas bagi guru SD Negeri Guwosari. Abdimas Dewantara, 1(1), 39-46.

[19] Ismah, Z., \& Ernawati, T. (2018). Pengaruh Model Pembelajaran Kooperatif Tipe Teams Games Tournament (TGT) Terhadap Hasil Belajar Ipa Siswa Kelas VIII SMP Ditinjau Dari Kerjasama Siswa. Jurnal Pijar Mipa, 13(1), 8285.

[20] Rahmatullah, M. J., Artayasa, I. P., \& Raksun, A. (2020). Perbandingan Kemampuan Berpikir Kritis dan Hasil Belajar IPA Menggunakan Model Pembelajaran Predict Observe Explain (POE) Dan Student Team Achicvment Division (STAD). Jurnal Pijar Mipa, 15(4), 416-423.

[21] Pohan, N. (2017). Pelaksanaan pembimbingan belajar aspek kognitif, afektif dan psikomotorik siswa di Madrasah Ibtidaiyah Swasta Amal Shaleh Medan. At-Tazakki: Jurnal Kajian Ilmu Pendidikan Islam dan Humaniora, 1(2), 15-28.

[22] Triowathi, N., \& Wijayanti, A. (2018). Implementasi team games tournament (tgt) dalam meningkatkan kerjasama dan hasil belajar IPA. Jurnal Pijar Mipa, 13(2), 110-118. 